\title{
Failure of Successful Intrasplenic Transplantation of Islets from Lean Mice to Cure Obese-Hyperglycaemic Mice, Despite Islet Growth
}

\author{
A. Andersson, U. Eriksson, B. Petersson, L. Reibring, and I. Swenne \\ Department of Medical Cell Biology, Biomedicum, University of Uppsala, Uppsala, Sweden
}

Summary. Implantation of allogeneic pancreatic islets encapsulated in Millipore diffusion chambers has been reported to normalize the obese-hyperglycaemic syndrome in mice. In the present study, both young and adult ob/ob mice remained hyperglycaemic and gained weight after intrasplenic implantation of 500 isogeneic islets isolated from lean mice. Such islets normalized the elevated blood-glucose of alloxan-diabetic lean mice. Morphometric analysis of the intrasplenically implanted islets showed that the mean islet volume in the ob/ob mice was five times larger than that of the lean, non-diabetic mice. Immunocytochemical staining of the spleens showed an increased proportion of B-cells in the enlarged, intrasplenic islets in the ob/ob mice. Moreover, autoradiographical examination of these islets demonstrated the presence of several labelled cells. These results suggest that the growth of the implanted "lean" islets is due to extrapancreatic factors which stimulate islet cell replication in the obese-hyperglycaemic mouse.

Key words: Obese-hyperglycaemic mice, isolated pancreatic islets, islet transplantation, serum glucose, islet volume, autoradiography, islet cell replication, immunocytochemistry

The obese-hyperglycaemic syndrome of the ob/ob mouse (gene symbol "ob") is genetically determined and characterized by over-eating, obesity, hyperglycaemia, hyperinsulinaemia and insulin resistance $[1$, $2,3]$. The aetiology of the syndrome is so far unknown, but disturbances in either hypothalamic or pancreatic islet function have been suggested to play a central role. The findings, by Strautz [4] and Gates et al. [5], that implantation of islets isolated from lean mice into obese mice ameliorates the obesehyperglycaemic syndrome were taken to suggest that the absence of an islet factor is responsible for the development of the syndrome.

The present study was performed to re-evaluate these latter findings by using the alternative transplantation technique of intrasplenic injection of syngeneic islets instead of Millipore chamber implantation. Particular attention was paid to the morphological fate of the grafted islets. Islets implanted intrasplenically into either normal or alloxan-diabetic lean animals served as controls.

\section{Materials and Methods}

\section{Animals}

Obese and non-obese mice of the inbred strain C57Bl/6J (Jackson Labs., Bar Harbour, Maine, USA) were obtained by breeding mice heterozygous for the obesity gene $(+/ o b)$. Some of the lean animals (heterozygous, $+/ \mathrm{ob}$ or homozygous, $+/+$ ) were injected IV with alloxan $(75 \mathrm{mg} / \mathrm{kg}$ body weight). All animals had free access to water and pelleted laboratory chow (Ewos-Anticimex, Type R3; Ewos AB, Södertälje, Sweden).

\section{Islet Isolation and Implantation}

Islets were isolated by means of a collagenase $(150-200 \mathrm{U} / \mathrm{mg}$; Worthington Biochemical Co., Freehold, New Jersey) digestion method [6] from non-obese or obese animals, which had been starved overnight. Groups of approximately 500 islets isolated from lean mice were suspended in Hanks' solution and injected intrasplenically into lightly anaesthestized (ether) animals, via a micro infusion set. Two groups of obese mice, consisting of animals weighing either 25-35 g or more than $40 \mathrm{~g}$ were used as recipients. Alloxan diabetic lean or normal lean mice were treated in a similar way. In addition, one group of alloxan diabetic animals received about 150 islets isolated from obese mice. Such a group of "obese" islets contains roughly the same amount of insulin as 500 "lean" islets but is twice as heavy in terms of dry weight. Every second week, all animals were weighed and blood samples for glucose determination were collected by retro-orbital puncture. The serum 


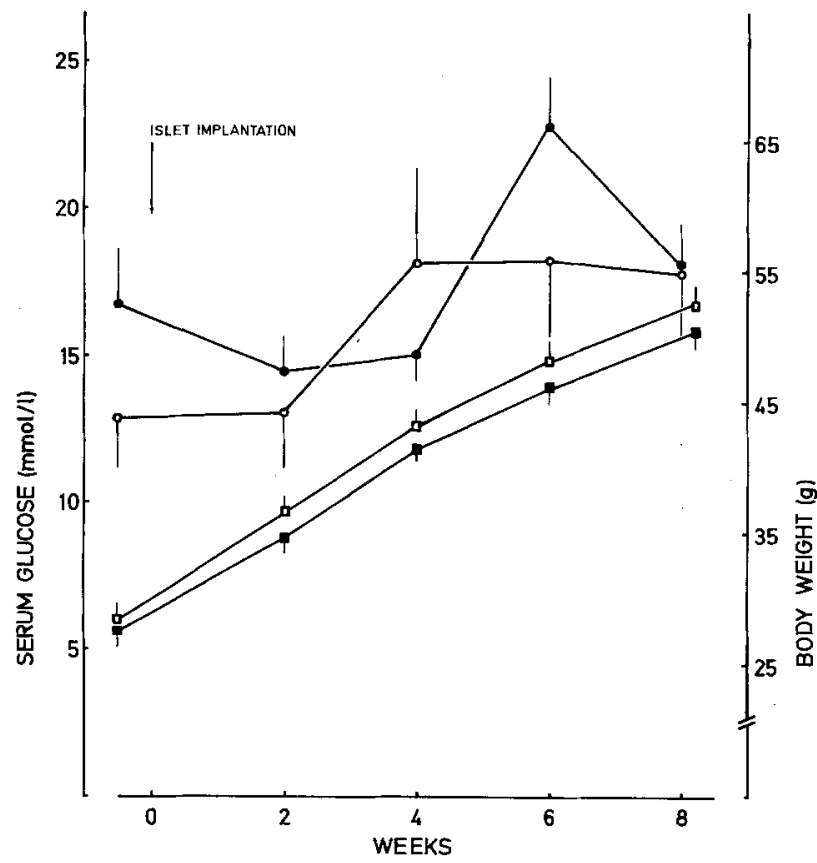

Fig. 1. Body weight (squares) and serum glucose (circles) values of islet-implanted (filled symbols; $\mathbf{n}=10$ ) or sham-operated (open symbols; $n=11$ ) young, obese mice. Mean \pm SEM

glucose concentration was determined with a glucose oxidase method using an automatic analyser (Beckman). Splenectomy was performed after 1 or 8 weeks. The alloxan diabetic animals were observed for a further three weeks to monitor reversion to the diabetic state.

\section{Histological Examination}

The removed spleens were fixed in Bouin's solution, embedded and sectioned. The sections were subsequently stained with haematoxylin-eosin or processed for immunohistochemical staining.

Guinea-pig anti-bovine insulin serum (diluted 1:320; Lot No GP-5, Miles Laboratories, Elkhart, Indiana, USA), rabbit antiporcine glucagon serum $(1: 80 ; \mathrm{K} 4023$; Novo Research Institute, Bagswaerd, Denmark) and rabbit anti-bovine PP serum (1:1600; kindly provided by $\mathrm{Dr} \mathrm{R}$. E. Chance) were used to demonstrate insulin, glucagon and pancreatic polypeptide (PP), respectively. Insulin and glucagon antibodies bound to the sections were demonstrated using the peroxidase-labelled antibody technique [7]. PP antibodies were demonstrated with the PAP-technique of Sternberger [8]. Control experiments were performed as recommended by Goldman [9] and included the application of antigeninactivated antisera.

\section{Morphometry}

To determine the mean volume of grafted islets, the spleens of the different groups of mice were sectioned serially $(7 \mu \mathrm{m})$ and stained with haematoxylin-eosin. Point sampling was not used, since determination of the total volume of islet tissue would be strongly dependent on the number of received and settled islets, which could be subject to variation. Therefore, the weighed mean islet volume of each recipient $(\bar{V})$ was used to give the mean islet vol-

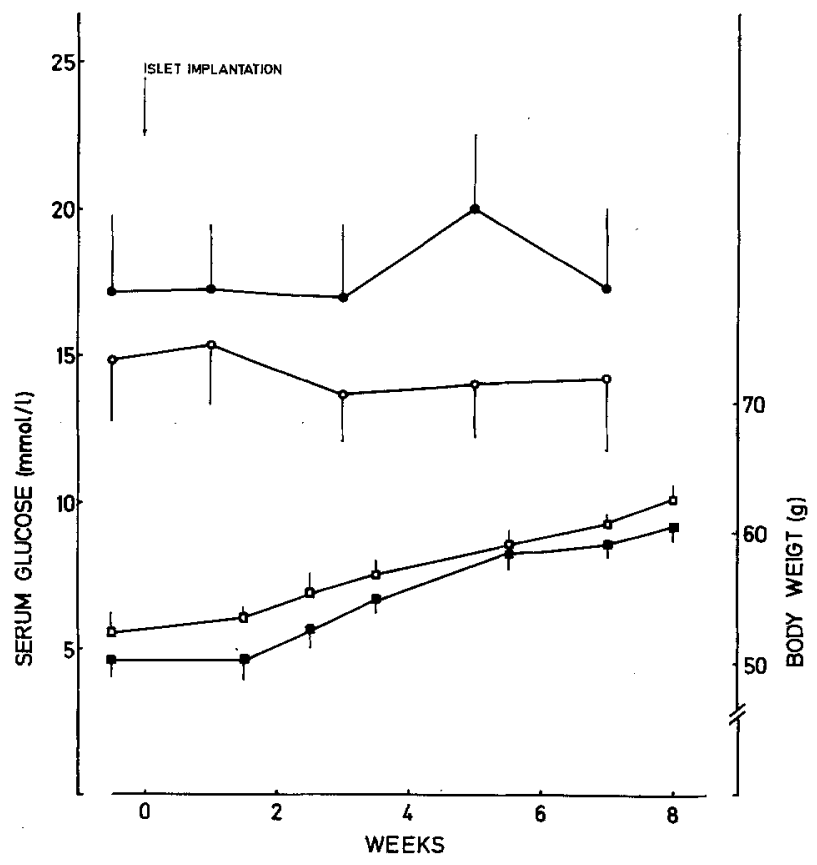

Fig. 2. Body weight (quadrangles) and serum glucose (circles) values of islet-implanted (filled symbols; $n=8$ ) or sham-operated (open symbols; $n=9$ ) adult, obese mice. Mean \pm SEM

ume $(\overline{\bar{V}})$ of the different experimental groups, which allowed comparison of islet growth by conventional statistical techniques. The transplanted islets were assumed to be of ellipsoidal shape, thus yielding elliptical islet sections. To estimate an individual islet sectional area, the two longest perpendicular diameters $(a, b)$ were measured to calculate the area (A)

$\mathrm{A}=\mathrm{a} \cdot \mathrm{b} \cdot \frac{\pi}{4}$

The volume $(\mathrm{V})$ of an islet was obtained by adding every third consecutive sectional area multiplied by the distance $(d=3 \times 7$ $=21 \mu \mathrm{m}$ ) between the sections,

$\mathrm{V}=\sum_{\mathrm{i}} \mathrm{a}_{\mathrm{i}} \mathrm{b}_{\mathrm{i}} \frac{\pi}{4} \mathrm{~d}$

where $a_{i}$ and $b_{i}$ respectively denote the long and short axis of the $i^{\text {th }}$ section.

By random sampling of the slides of one animal, without any correction for differences in islet size, 9-20 islet section surfaces were chosen and the volumes (V) of the corresponding islets were determined as outlined above.

The probability of choosing an islet is proportional to its mean diameter, the cubic root of its volume $\left(\mathrm{V}^{1 / 3}\right)$. Therefore, the weighed mean islet volume $(\bar{V})$ of each animal was obtained according to the following formula:

$\bar{V}=\frac{\sum_{j} V_{j} V_{j}^{-1 / 3}}{\sum_{j} V_{j}^{-1 / 3}}=\frac{\sum_{j} V_{i}^{2 / 3}}{\sum_{j} V_{j}^{-1 / 3}}$

where $V_{j}$ denotes the volume of the $j^{\text {th }}$ islet. The mean islet volumes $(\overrightarrow{\mathrm{V}})$ and standard deviations of each experimental group could then be calculated and compared using Student's two-tailed t-test. 


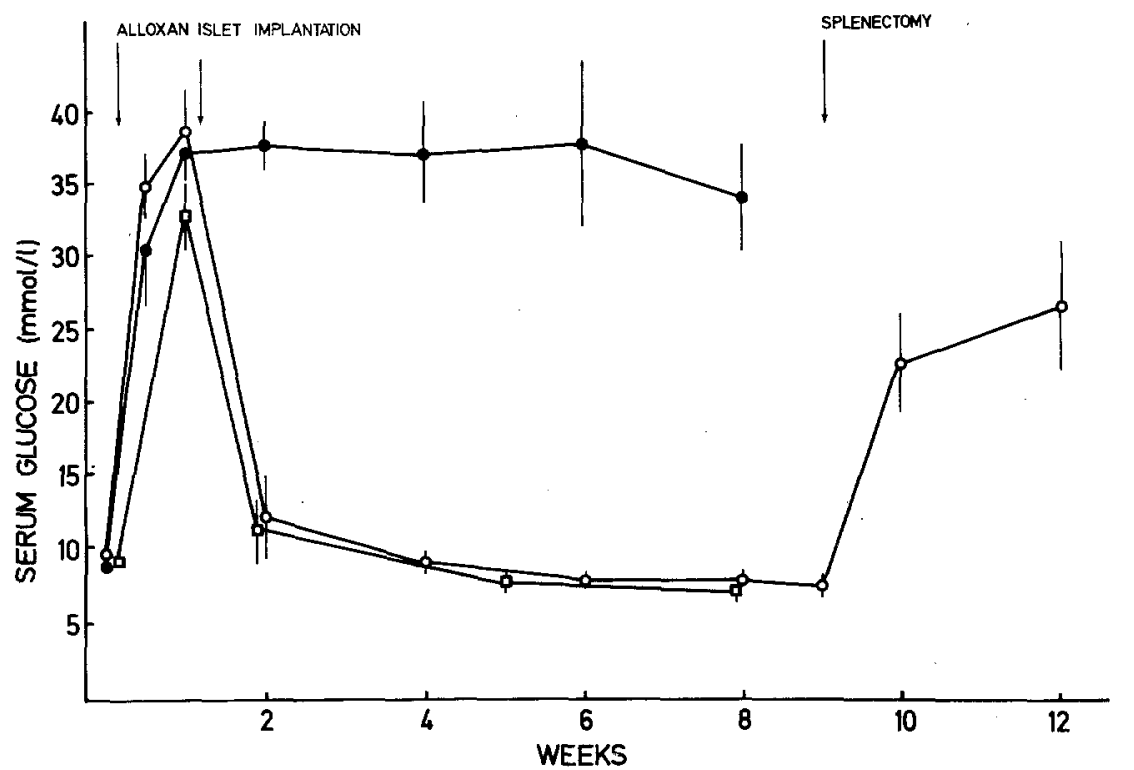

Fig. 3. Serum glucose values of alloxandiabetic lean mice before and after islet implantation. $\mathrm{O}-\mathrm{O}$, mice implanted intrasplenically with 500 islets isolated from lean mice. These animals were splenectomized eight weeks after the transplantation $(\mathrm{n}=6)$. $\square-\square$, mice implanted with 150 islets isolated from obese mice $(n=6)$. - - serum glucose values of shamoperated mice $(\mathrm{n}=3)$. Mean \pm SEM

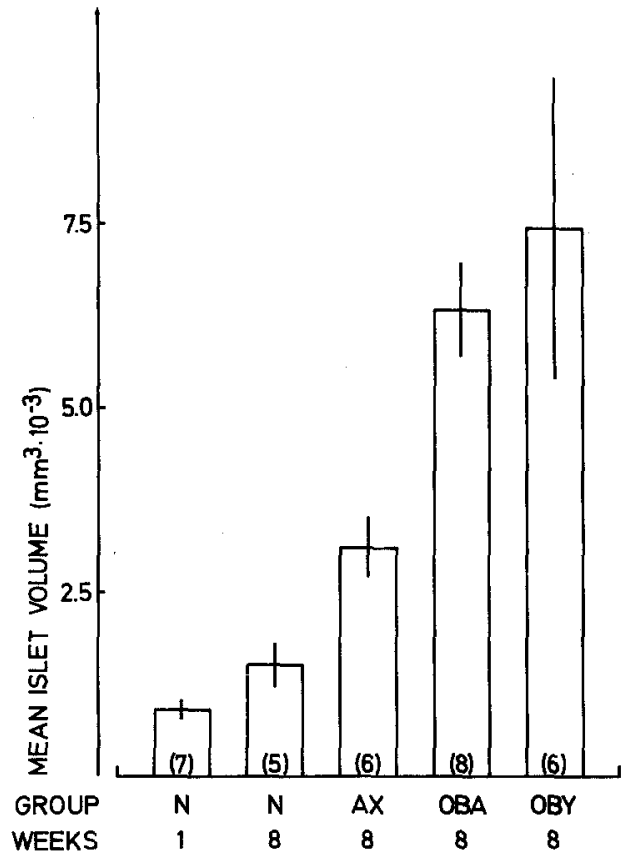

Fig. 4. Mean islet volume of intrasplenically implanted islets 1 or 8 weeks after the transplantation. For further details, see morphometry section of Materials and Methods. $\mathrm{N}=$ normal, lean mice. $\mathrm{AX}=$ alloxan-diabetic, lean mice. OBA $=$ adult, obese mice $(>40 \mathrm{~g})$. OBY $=$ young, obese mice $(<35 \mathrm{~g})$. Mean \pm SEM

\section{Autoradiography}

Animals intended for autoradiographic studies were injected with tritiated thymidine $(1 \mu \mathrm{Ci} / \mathrm{g}$ body weight; specific activity $5 \mathrm{Ci} /$ mmol; The Radiochemical Centre, Amersham, UK) $2 \mathrm{~h}$ prior to sacrifice. The spleen, the pancreas and part of the small intestine were removed and fixed in Bouin's solution. The fixed tissue was prepared for histology as above and then sectioned $(7 \mu \mathrm{m})$. The slides were dipped in Ilford $\mathrm{K} 2$ emulsion and exposed for 2 weeks at $+4{ }^{\circ} \mathrm{C}$. The dipped slides were subsequently developed in Kodak D-19 for $6 \mathrm{~min}$, fixed in Kodak F-24 for $6 \mathrm{~min}$, counterstained with haematoxylin-eosin and mounted.

\section{Results}

\section{Effects of Islet Implantation on Body Weight and Serum Glucose}

"Lean" islet implantation did not influence the progressive weight gain of the young obese animals weighing less than $35 \mathrm{~g}$ (mean $\pm \mathrm{SE}, 27.9 \pm 0.8 \mathrm{~g}$ ) at the onset of the experiments (Fig. 1). The implanted islets also had no effect on the hyperglycaemia of these animals. Similar observations were made when the islets were injected into older obese mice (Fig. 2), those weighing more than $40 \mathrm{~g}(52.5 \pm 1.4 \mathrm{~g})$.

Intrasplenic implantation of "lean" islets into alloxan diabetic lean mice resulted in prompt restoration of normoglycaemia (Fig. 3). When splenectomy was performed 8 weeks after the transplantation, all these animals again became hyperglycaemic. Figure 3 also shows that 150 "obese" islets were equally effective as 500 "lean" islets in correcting the hyperglycaemia of the alloxan-diabetic lean mice.

\section{Morphology of the Implanted Islets}

In general, the intrasplenically implanted islets were morphologically well preserved and delineated from the surrounding splenic pulp by a thin connective tissue capsule. Blood cell containing capillaries were frequently observed within the islets. The morphometrical estimations of islet size (Fig. 4) showed that islets which had been located in the spleen of normal lean mice for eight weeks tended to be larger 
than those in animals sacrificed one week after islet implantation. A further greater increase in size of the grafted islets was recorded in the alloxan diabetic lean mice. Indeed, there was a 2 -fold increase in implanted islet size as compared to values observed in control animals 8 weeks after transplantation $(p<0.02)$. Even larger increases in transplanted islet size were observed in the obese animals. Thus, islets implanted into the obese mice were either four times (older animals) $(p<0.01)$ or five times (younger animals) $(p<0.05)$ larger than the islets of the controls.

\section{Immunocytochemical and Autoradiographical Studies}

These qualitative studies of the islet grafts were confined to two groups of mice, namely the 8 week lean controls and the younger, implanted obese mice. The islets of the latter group were predominantly composed of insulin-positive cells but the intensity of the staining was low, probably due to the degranulation of the B-cells. The frequency of glucagon-positive cells was low. The islets of both groups of animals contained relatively few PP-positive cells.

In both groups of mice there were a lot of heavily labelled cells in the intestinal mucosa, confirming the successful introduction of ${ }^{3} \mathrm{H}$-thymidine into the mice. Moreover, several labelled cells were found in the endocrine pancreas of the obese mice, whereas hardly any labelled cells were observed in the islets of the lean mice. The same pattern of cell labelling was found in the islets implanted into the spleens of these groups of mice. Thus, almost all spleen sections of the obese mice contained one or several labelled islet cells, whereas the islets located in the spleens of the lean mice only very occasionally displayed labelled cells.

\section{Discussion}

The present data indicate that syngeneic intrasplenic implantation of islets isolated from lean mice into obese-hyperglycaemic mice does not cure the recipient. The same amount of islet tissue does, however, consistently cure alloxan-diabetic lean mice. Thus, there was no reduction of the obesity of the adult animals, and no prevention of the progressive weight gain of the young, obese mice. Moreover, both groups of animals remained hyperglycaemic throughout the 8 week observation period. This finding is in complete contrast to that of Strautz [4] who demonstrated a return to normoglycaemia in animals transplanted with only half the number of islets (250) used in this study. Similarly, Barker et al. [10] have been unable to reproduce the results of either Strautz [4] or Gates et al. [11], who claimed to have ameliorated the abnormalities of both obese-hyperglycaemic and New Zealand obese mice by allogeneic implantation of islets. Both of these latter reports used Millipore bags as a tool for preventing rejection. There is now, however, a growing body of evidence that islet function and survival is not maintained in such devices [12]. It is of special interest that Theodorou and Howell [13], in their assessment of diffusion chambers for pancreatic islet cell transplantation, found that the half-time for transit of glucose into the chambers was about $14 \mathrm{~min}$ and that of insulin out of the chambers, $54 \mathrm{~min}$. In a recent study, these workers also failed to cure diabetic rats using syngeneic islet transplants, with the islets encapsulated in diffusion chambers [14].

On the other hand, it seems unlikely that one would cure genetically diabetic mice by augmenting their capacity to produce insulin by islet transplantation, since they are already hyperinsulinaemic. Otherwise, it would need to be assumed that the insulin of these obese mice is biologically less efficient. The observation that the islets isolated from both ob/ob (present study) and db/db mice [10] were at least as equally effective as "normal" islets in restoring normoglycaemia in chemically diabetic mice, contradicts such a hypothesis. On the other hand, even though the serum insulin concentrations of these obese mice are high, they might still be relatively hypoinsulinaemic. Our present finding, that the further additional supply of insulin brought about by the "lean" islet implantation was ineffective in reversing their hyperglycaemia, however rather speaks in favour of peripheral insulin resistance as being the aetiological factor of greatest importance.

Alternatively, it seems plausible to speculate, as Strautz [4] did, on the presence, in the islets, of a "non-insulin" factor, which may be lacking in the endocrine pancreas of the ob/ob mouse. Indeed, pancreatic polypeptide has been suggested to be such a factor, since administration of this islet hormone into obese mice reduces food intake and suppresses body weight gain [15]. Furthermore, Gates and Lazarus [16] demonstrated that IP injections of avian or bovine PP were capable of normalizing the hyperinsulinaemia, hyperglycaemia and weight gain of New Zealand obese mice. One possible explanation for our failure to cure the obese-hyperglycaemic mice could be that the implanted islets were predominantly from the body and tail of the pancreas, areas which are known to possess few or no PP-containing cells [17]. Immunocytochemical staining of the recipient spleens, however, showed that PP-cells were present in the grafted islets. The observation that the number of PP-cells per average islet was three times greater in the pancreas of ob/ob mice [18] gives 
further support to the view that a lack or reduction of pancreatic polypeptide should not be responsible for the obese-hyperglycaemic syndrome.

It has previously been demonstrated that fetal islet grafts increased in volume by a factor of twentysix three weeks after implantation to the renal subcapsular site of alloxan diabetic rats [19]. The extensive growth of the islets implanted into the obese mice clearly indicates that islet cells prepared from adult mice are also capable of regenerating when exposed to certain environments. It could be argued that our present finding of a comparative increase in islet size in the spleens of the obese animals is not due to a real net growth but rather to a successive decrease in size of the islets of the control mice. The presence of many labelled cells and occasional mitotic figures in the former islets do not, however, speak in favour of such a hypothesis. Indeed, our quantitative studies of the ${ }^{3} \mathrm{H}$-thymidine $\mathrm{B}$-cell index indicate that there is an almost tenfold increase in the labelling index of the islets implanted into the ob/ob mice (Swenne and Andersson, unpublished observations). Moreover, the number of labelled islet cells in these mice seemed to be approximately the same in both the implanted and endogenous islets.

The present data lend no further support to the idea that the hyperplasia of the endocrine pancreas of the obese-hyperglycaemic mice may be due to a factor(s) present within the islets. It rather appears that this factor(s) may be circulating, and reaching islet grafts located outside the pancreas. Two such possible factors are the hyperglycaemia and the hyperinsulinaemia. The finding that the islets implanted into the hyperglycaemic alloxan-diabetic lean mice did not grow as much as those injected into the obese mice does not, however, rule out the possible importance of hyperglycaemia, since the alloxan-diabetic mice recovered from hyperglycaemia shortly after islet implantation. The islets were therefore subject to hyperglycaemia for only a few days. This question is currently being considered by observing the fate of islets implanted in insufficient numbers to decrease the elevated blood glucose of the recipient.

Acknowledgements. The skilled technical assistance of Astrid Nordin, Ewa Hansson, Margareta Engkvist, Christina Bittkowski and Eva Törnelius is gratefully acknowledged. Financial support was received from the Swedish Medical Research Council (12X-109; $12 \mathrm{X}-2297 ; 16 \mathrm{X}-4527)$, the Swedish Diabetes Association, the Medical Faculty of the University of Uppsala and the Nordic Insulin Fund.

\section{References}

1. Ingalls AM, Dickie MM, Snell GD (1950) Obesity, a new mutation in the house mouse. I Hered 41: 317-318

2. Bleisch VR, Mayer J, Dickie MM (1952) Familial diabetes mellitus in mice, associated with insulin resistance, obesity, and hyperplasia of the islets of Langerhans. Am J Pathol 28: 369-381

3. Westman S (1968) Development of the obese-hyperglycaemic syndrome in mice. Diabetologia 4: 141-149

4. Strautz RL (1970) Studies of hereditary-obese mice (obob) after implantation of pancreatic islets in Millipore filter capsules. Diabetologia 6: 306-312

5. Gates RJ, Hunt MJ, Smith R, Lazarus NR (1972) Return to normal of blood-glucose, plasma-insulin, and weight gain in New Zealand obese mice after implantation of islets of Langerhans. Lancet II: 250-253

6. Howell SL, Taylor KW (1968) Potassium ions and the secretion of insulin by islets of Langerhans incubated in vitro. Biochem J 108: 17-24

7. Sternberger LA (ed) (1974) In: Immunocytochemistry. Prentice-Hall, Englewood Cliffs, p 118-121

8. Sternberger LA (ed) (1974) In: Immunocytochemistry. Prentice-Hall, Englewood Cliffs, p 143-144

9. Goldman M (ed) (1968) In: Fluorescent antibody methods. Academic Press, New York, p 153-172

10. Barker CF, Frangipane LG, Silvers WK (1977) Islet transplantation in genetically determined diabetes. Ann Surg 186: $401-409$

11. Gates RJ, Hunt MJ, Lazarus NR (1974) Further studies on the amelioration of the characteristics of New Zealand obese (NZO) mice following implantation of islets of Langerhans. Diabetologia 10: 401-406

12. Garvey JFW, Morris PJ, Finch DRA, Millard PR, Poole M (1979) Experimental pancreas transplantation. Lancet I: 971-972

13. Theodorou NA, Howell SL (1979) An assessment of diffusion chambers for use in pancreatic islet transplantation. Transplantation 27: 350-352

14. Theodorou NA, Vrbova H, Tyhurst M, Howell SL (1980) Problems in the use of polycarbonate diffusion chambers for syngeneic pancreatic islet transplantation in rats. Diabetologia 18: $313-317$

15. Malaisse-Lagae F, Carpentier J-L, Patel YC, Malaisse WJ, Orci L (1977) Pancreatic polypeptide: A possible role in the regulation of food intake in the mouse. Hypothesis. Experientia 33: 915-917

16. Gates RJ, Lazarus NR (1977) The ability of pancreatic polypeptides (APP and BPP) to return to normal the hyperglycaemia, hyperinsulinaemia and weight gain of New Zealand obese mice. Horm Res 8: 189m-202

17. Orci L, Baetens D, Ravazola M, Stefen Y, Malaisse-Lagae F (1976) Pancreatic polypeptide and glucagon: Non-random distribution in pancreatic islets. Life Sci 19: 1811-1816

18. Gingerich RL, Gersell DJ, Greider M, Finke EH, Lacy PE (1978) Elevated levels of pancreatic polypeptide in obesehyperglycemic mice. Metabolism 27: 1526-1532

19. Hegre OD, Leonard RJ, Erlandsen SL, McEvoy RC, Parsons JA, Elde RP, Lazarow A (1976) Transplantation of islet tissue in the rat. Acta Endocrinol [Suppl] (Kbh) 205: 257-278

Received: July 7, 1980,

and in revised form: October 29, 1980

Dr. Arne Andersson

Department of Medical Cell Biology

Biomedicum

P. O. Box 571

S-751 23 Uppsala

Sweden 